\title{
USE OF THE DIRECT METHOD FOR EVALUATION AND VALUATION OF THE LANDSCAPE VISUAL QUALITY
}

\author{
COSTA, T. ${ }^{1 *} ;$ LAMPERT, A. D. C. ${ }^{2}$ \\ 1.Programa de Pós-Graduação em Ciência e Tecnologia Ambiental, Universidade do Vale do Itajaí - \\ UNIVALI, Itajaí-SC, Laboratório de Gerenciamento Costeiro Integrado \\ 2. Programa de Pós-Graduação em Ciência e Tecnologia Ambiental, Universidade do Vale do Itajaí - \\ UNIVALI, Itajaí-SC, Laboratório de Biorremediação Ambiental
}

*Corresponding author: taliadacosta@yahoo.com.br

\begin{abstract}
Costa, T.; Lampert, A.D.C., 2017. Use of the direct method for evaluation and valuation of the landscape visual quality. Braz. J. Sci. Technol. 21(2). eISSN 1983-9057. DOI:12475/bjast.v21n2. The concept of landscape is used by the most diverse areas such as geography, architecture, plastic arts, psychology and the environmental area where it receives an important role in the management of environmental resources. The direct method evaluates the visual quality of the landscape from the contemplation of its totality, through the visualization at the site or through the use of substitutes giving rise to different levels of subjectivity during the process. The scale used to evaluate the landscape visual quality comprised integer values equal to one, two, three, four and five, corresponding to very low, low, good, high and very high visual quality classes, respectively. Of the 21 photos evaluated, only two photographs received the extreme ratings.
\end{abstract}

Key Words: landscape, direct method, valuation

\section{INTRODUCTION}

Landscape references appeared about 1000 BC in the Old Testament "Book of Psalms," with its initial notion as visual and aesthetic (Metzger, 2001). Over the years, the initial notion began to be integrated by literature and mainly by painting in the second half of the 18th century, where it received a sense of melancholy and solitude beyond the real sense of beauty of nature Metzger (2001).

The landscape is understood as the sense of the terrain in a field of vision, experienced and related according to the observer, and can have the sense of scenic beauty, organization, territorial occupation, modification of nature, relations of biota and stage of historical events, all with notion of amplitude and distance. Thus, according to Metzger (2001) the concept of landscape has two approaches: one ecological and one geographical. The ecological approach seeks to apply the concepts of ecology to the conservation of biological diversity, with natural resource management and the influence of ecosystem ecology. On the other hand, the geographic approach attentive to territorial planning, seeking the visual and spatial entity of the space lived by man added to the temporal scale.

For Bertrand (1972), the landscape is not simple addition of disparate geographical elements. It is the result of the dynamic and therefore unstable combination of physical, biological and anthropic elements which, by reacting dialectically to one another, make the landscape a unique and inseparable whole, in perpetual evolution, in a certain portion of space.
The landscape can also be defined as a perceived or felt spatial unit resulting from the heterogeneous combination of biotic, abiotic and socioeconomic elements at different spatiotemporal scales (Formam \& Gordon, 1986).

According to Odum \& Barrett (2011) the landscape encompasses people and nature, serving as a fundamental instrument for integrated studies of the environment where the landscape is understood as a key concept necessary for integrated understanding of the environment. Oliveira (1999) states that the landscape is the result of natural processes and anthropic actions occurring in a given area over time. Thus, landscape is associated with the passage of time over a given area and / or place.

As a definition of landscape, it is proposed as a "heterogeneous mosaic formed by interactive units, and this heterogeneity exists for at least one factor, according to an observer and on a certain scale of observation" (Metzger, 2001). Thus the observer elaborates a reality when he aesthetically interprets the landscape he is seeing. This interpretation may be natural, cultural or urban. It is the domain of the visible or of all that the senses reach, being able to be formed as much by odors as by sounds or movements (Pires, 1996).

Considering the perspective of the landscape, according to Verdum et al. (2016), one can have the landscape as something concrete and the landscape as a phenomenon. The concrete landscape is understood as a result of the marks that the human society imprints on the terrestrial surface over time, condi- 
tioned by geological, geomorphological, ecological and climatic factors in constant transformation by physical, social, economic and cultural dynamics. This approach highlights two important variables that influence the constitution of the landscape: time and materiality. The second perspective considers the landscape as a phenomenon. The phenomenological aspect of the landscape lies, then, in the different and infinite modes of the subject, looking, interpreting and transforming the geographical space. This reading of the landscape is a continuous social and at the same time private construction, where the identity, knowledge, memory and feelings of each person are associated with the cultural process that refers to the collective organization.

The use of the photographic image, from the beginning of its use, is accepted by common sense - and partly by the technical-scientific means - as an image of reality. According to Dearde (1981), one of the first systematic studies to evaluate the visual quality of the landscape, which includes representativity through photography, was elaborated by Fines (1969) who used 45 evaluators, a standard control photograph and an elaborated value scale by the evaluators.

For some scholars, landscape photography, like any other photograph, is of open meaning, as part of the reality transfigured into an image, loses some of its actual space-time connections. Therefore, some studies cite problems regarding the use of photography to assess the landscape. However, Zube \& Pitt (1981), in a study related to the validity of the use of photographs, find a strong correlation between participants who were evaluated through photos and those who went to the field. This corroborates with Oliveira Junior (2007), who cites that the photographic landscape acquires singularity through its constituent elements and the objectives of its production, at the same time that it gives meaning to the natural reality.

The photographs can be used to evaluate the components of the landscape and the visual quality of the landscape. Therefore, according to Pires (1993) there are three methods of evaluation and / or assessment of the visual quality of the landscape: i) indirect method which is applied through the analysis of the physical components (abiotic environment), biological components (biotic medium ) and anthropogenic components (land use) which are assessed by means of regular units (reticulated mesh) or irregular units (depending on a landscape component, for example); ii) direct method where the valuation is realized from the totality contemplation of the landscape, by the visualization in the place or by the use of substitutes (photographs, slides, videos or engravings), giving rise to different levels of subjectivity during the process and iii) mixed method being the assessment done directly, and then, through statistical analysis, the study of the participation of each component or element in the total value of the landscape. For the present study, the direct method of visual landscape quality analysis was chosen.

\section{MATERIALS AND METHODS}

The landscape structure characterization was performed using the direct method of evaluating the visual quality of the landscape, with a valuation based on aesthetic appreciation of the landscape, using a substitute (photographs). The physical, biological and anthropic factors were evaluated and interpreted together, with the function of qualifying their components for the evaluation of the visual quality of each of the photographs. The scale used to evaluate the visual quality of the landscape comprised integer values equal to one, two, three, four and five, corresponding to very low, low, good, high and very high visual quality classes, respectively.

A total of 21 photographs (Figure 1) were used, which were evaluated subjectively by 20 masters and doctoral students of the Postgraduate Program in Environmental Science and Technology of the University of Vale do Itajaí - UNIVALI. The photographs were chosen randomly, containing elements of urbanization and natural elements arranged in a combined manner or not.

The assessment sheet contained 21 rows for the landscape analysis observations and 21 cells for the placement of the grades (one to five). Each photo can be viewed a total of three times, for an average time of one minute at a time. No parameters were stipulated for landscape evaluation, following the subjectivity of the direct method.

\section{RESULTS}

The results obtained from the visual quality analysis of substitutes by the direct method can be observed in Table 1.

The landscapes classified with high visual quality (value four) and very high (value five) were those that presented a greater amount of natural elements and a smaller amount of elements related to urbanization / anthropization. Only number 13 photo was rated with very high visual quality. In this photograph there are no anthropogenic / urbanistic components, with only natural components. Photographs $3,4,6,11,14$, $18,19,20$ and 21 were classified as high visual quality. This classification was the one that obtained the largest number of photographs which presented characteristics with a large proportion of natural components. In them, the urbanization components were not enough to cause visual quality depreciation. 
Figure 1 - Photographs evaluated by direct visual quality method of the landscape.
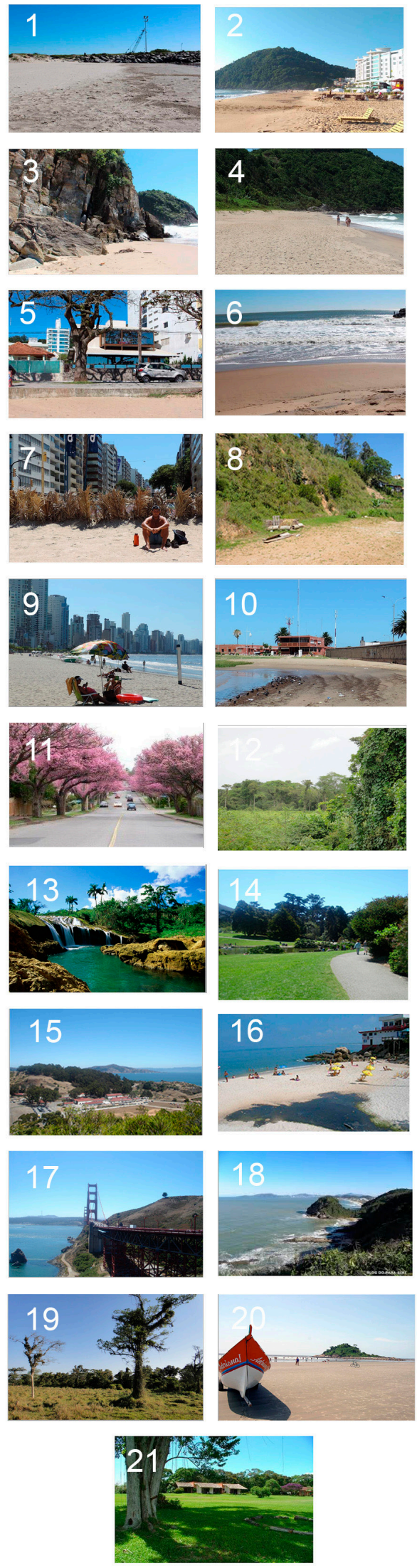

The landscapes of low class (value two) and very low (value one) presented, in general, a great amount of elements of urbanization, in relation to the other classes. In addition, they also presented a considerable amount of elements that denote pollution, including landscapes with a reasonable amount of natural elements. Photographs of numbers 1, 5, 7, 8, 10 and 16 were part of these classifications, with only the photograph of number 8 being classified as very low. Most of the observations made by the appraisers, in the evaluation form, had the requirements urbanization and lack of natural elements as justification for the lowest grade.

Those of good visual class (value three) presented balanced natural and anthropized elements. However, some landscapes presented only natural elements, but without their diversity. It can be inferred that the lack of diversity of the natural elements does not appeal so much, visually. In addition, the photograph of number 9 presents, in its background, the massive presence of buildings, being in the same classification of other photographs where the presence of the urbanization is not so accentuated. The need for a diversity of natural elements and the less importance of the urban elements is then perceived when there is, in the same field of view of the assessor, the presence of the natural beach element.

\begin{tabular}{|l|l|}
\hline Number of Evaluated Photography & \multicolumn{1}{|c|}{ Visual Quality Classification } \\
\hline 8 & Very low \\
\hline $1,5,7,10$ e 16 & Low \\
\hline $2,9,12,15,17$ & Good \\
\hline $3,4,6,11,14,18,19,20$ e 21 & High \\
\hline 13 & Very high \\
\hline
\end{tabular}

Table 1: Results of visual quality of 21 photographs analyzed by academics of the Postgraduate course in Environmental Science and Technology - UNIVALI

\section{DISCUSSION}

Among the various attributes of the landscape, it is possible to distinguish some in particular that allow predicting a positive relationship, explored and cited by several authors in their studies, such as: water, cited by Ariazza et al. (2004) and Acar et al. (2006); vegetation, cited by Lothian, (2000); monuments constructed by man, cited by Ariazza et al. (2004), among others. The results presented in this article are in agreement with Vieira et al. (2007), who affirm that the landscape preference of valuators is associated with the naturalness of the landscape as well as the balance and harmony between the elements. These results are also in agreement with Canteras (1992), in which the diversity of elements, forming a landscape variety, has more value than a homogeneous landscape. Besides that, regardless of the skills and knowledge 
of each observer, it is accepted that the quality of the landscape derives from an interaction between their biophysical characteristics, the perceptive processes and the experiences and knowledge of the observer (Loures et al., 2014).

This explains the choice of number 13 photo as the preferred choice among the evaluators. In this photograph there is a combination of components, generating colors, so, there is no monotony in photography. In addition, the water element appears well represented in landscape 13. This element is considered by Tuan (1980), Pires (1993) and Burmil et al. (1999), one of the most important and attractive visual elements of the landscape, besides being very important for the human being, not only in the biological sense, but also on the appreciative side. According to Tuan (1980), the enchantment of the human being by water must be something inherited from the ancestors who sought to establish themselves near rivers, lakes and beaches appropriate for obtaining food, fixation, reproduction, learning and development of manual skills. Yázigi (2002) stated that studies carried out in several countries showed that the preference of people is for landscapes that presented the water element, with the exception of some people in Africa, who preferred mountains and fields. Regarding the most relevant landscape parameters, considering the quality of the landscape, Ayala et al. (2003) found that $23.60 \%$ of respondents felt that presence of water is the most significant parameter in the quality of this landscape.

Added to this, vegetation also appears around the river and, according to Yázigi (2003), rivers surrounded by vegetation are an intense source of attraction for people, not being fundamental for the good valuation of the landscape.

Some photographs that presented high visual quality had urban elements, but the infrastructure is also in harmony with the landscape. For Boullón (2002) this may represent a landmark in the landscape, acting as an outstanding urban artifact also serves as a point of reference for the observer, able to increase the preference for the landscape. On the other hand, when asked about the influence of the urban construction in the degradation of the landscape, most of the respondents, according to Ayala et al. (2003), considered that urban construction influences negatively the overall landscape quality. In addition, Felix et al. (2016) found that visual quality was sensitive to human interventions, and landscape units of urbanized sandy beaches were rated lower than those of semiurbanized beaches.

The presence of exposed soil and possible pollution were essential characteristics to damage the landscapes and to classify them in very low and low visual quality. In some photographs classified as low visual quality, the mixture of urban and natural elements was a derogatory element in the landscape. This is contrary to Nigro \& De Angelis (2016) who cite in their studies that the landscape composed of natural elements within urban space can be highly valued due to the mixture of urban and natural elements.

According to Bobrowski et al. (2010), the presence of vegetation is not a determining factor and a major element for the attribution of beauty to landscapes, although it is an important element in the valuation of the landscape, which explains the classification of photography number 12 , which is composed only by one component, the vegetable, inserted into the good visual class.

Ayala et al. (2003) defines as relevant for the analysis of Landscape Visual Quality Assessment: vegetation, land use, slope, physiography, size and shape of the visual basin, and distance to roads, paths, and urban centers. Regarding the analysis of the Landscape Visual Fragility, the same author considers the physical geography, vegetation and land use, the presence of water, and the degree of humanization.

\section{CONCLUSION}

Studying the visual quality of the landscape can be a potential alternative for studies related to conservation units and their management plans as well as a tool for the environmental management process. The use of substitutes to assess the visual quality of the landscape is important, especially for the time savings, since several substitutes can be evaluated in a short time. The perception of the valuers directly influences the results obtained for the visual quality of the landscape, especially in the use of the direct evaluation method. The natural elements in the photographs resulted in the highest ratings. However, the lack of diversity of natural elements negatively influenced the classification of photographs. It is verified that the heterogeneity of elements, including the composition of natural elements with urban elements in the photographs, caused a better impression for the evaluators of the present study.

\section{REFERENCES}

Acar C., Kurdolu B., Kurdolu O., Acar H. (2006). Public preferences for visual quality and management in Kaçkar Mountains National Park (Turkey), Int. J. Sustain. Dev. World Ecol. 13(6): 499-512.

Arriaza M., Cañas-Ortega, J. F., Cañas-Madueño, J. A. and Ruiz-;Aviles, P.(2004). Assessing the visual quality of rural landscapes. Landscape and Urban Planning, 69(1): 115-125.

Ayala, R., Ramirez, J. and Camargo, S. (2003), Valoración de la calidad y fragilidad visual del 
paisage en el Valle de Zapotitlán de las salinas, Puebla (México). Faculdade de Geografia e Historia da Universidade de Madrid, Madrid.

Bertrand, G. 1972. Paisagem e geografia física global - esboço metodológico. Caderno de Ciências da Terra. Instituto de Geografia, São Paulo. 13: 01-27. Bobrowski, R; Biondi, D.; Vashchenko, Y. 2010. Qualidade visual da paisagem do Parque Natural Municipal Tanguá, Curitiba - PR. Revista da Sociedade Brasileira de Arborização Urbana, Piracicaba. 5(2): 19-39.

Boullón, R.C. 2002. Planejamento do Espaço Turístico. Bauru, SP: EDUSC, 2002.

Burmil, S.; Daniel, T.C.; Hetherington, J.D. 1999. Human Values and Perceptions of Water in Arid Landscapes. Landscape and Urban Planning, 44: 99-109.

Canteras, J.C. 1992. Introducción al paisaje. Curitiba: UFPR e Universidad de Cantabria, 60p.

Dearden, P. 1981. Public participation and scenic quality analysis. Landscape Planning. Amsterdam. 8: 3-19.

De Oliveira Junior, A. 2007. Paisagem na fotografia: sentidos e plasticidades. Conexão - Comunicação e Cultura, UCS, Caxias do Sul. 6(12).

Felix, G., Marenzi, R. C., Polette, M. and Netto, S. A. 2016. Landscape Visual Quality and Meiofauna Biodiversity on Sandy Beaches. Environmental Management. 58:682-693.

Fines, K.D. 1969. Landscape evaluation: a research project in East Sussex: Rejoinder to critique by D.M. Brancher. Regional Studies. 3: 219.

Forman, R.T.T.; Godron, M. 1986. Landscape ecology. New York: John Wiley \& Sons, 619p.

Lothian, A. 1999. Landscape and the philosophy of aesthetics: is landscape quality inherent in the landscape or in the eye of the beholder. Landsc Urban Plan. 44(4):177-198.

Loures, L., Loures, A., Nunes, J. and Panagopoulos, T. 2014. Using direct and indirect methods of landscape evaluation on environmental amenities' valuation. Advances in Environmental Sciences, Development and Chemistry. Greece. 104-108.

Metzger, J.P. 2001. O que é ecologia de paisagens? Biota Neotropica. UNICAMP, Campinas. 1(12).

Nigro, G.T.; De Angelis, B.L.D. 2016. Avaliação da qualidade paisagística para o uso turístico do parque do Ingá, Maraingá (PR). Revista da Sociedade Brasileira de Arborização Urbana. Piracicaba. 11(3): 17-36.

Odum E.P.; Barrett, G. W. 2011. Fundamentos de ecologia. $5^{a}$ edição. Cengage Learning, São Paulo. 823p.

Oliveira, J.P. 1999. Glossário de Turismo e Hotelaria. Revista Turismo Visão \& Ação. Edição Especial.
Pires, P. dos Santos. 1993. Avaliação da qualidade visual da paisagem na região carbonífera de Criciúma - SC. Dissertação de Mestrado em Engenharia Florestal - Faculdade de Engenharia Florestal, Setor de Ciências Agrárias, Universidade Federal do Paraná. Curitiba.

Pires, P. dos Santos. 1996. Paisagem litorânea de Santa Catarina como recurso turístico. In: YÁZIGI, E., CARLOS, A. F. A., CRUZ, R. de C. A. da (orgs.). Turismo: espaço, paisagem e cultura. pp. 161-177. São Paulo : HUCITEC.

Tuan, Y.F. 1980. Topofilia. Um Estudo da Percepção, Atitudes e Valores do Meio Ambiente. São Paulo: Difel.

Verdum, R., Vieira, L.F. dos Santos, Pimentel, M.R. 2016. As Múltiplas Abordagens para o Estudo da Paisagem. Espaço Aberto, PPGG - UFRJ. 6(1): 131-150.

Vieira, R., Mussi, S.C. \& Pires, P.S. 2007. Estudo sistêmico da paisagem no empreendimento turístico "llha de Porto Belo" em Santa Catarina, Brasil, na perspectiva de sua sustentabilidade. Rev. Bras. Pesq. Tur. São Paulo, 11(2): 218-238.

Yázigi, E. 2002. AAlma do Lugar. Turismo, Planejamento e Cotidiano em Litorais e Montanhas. $2^{a}$ Ed. São Paulo: Contexto (Coleção Turismo Contexto).

Zube, E.H.; Pitt, D.G. 1981. Cross-Cultural Percepcions of Scenic and Heritage Landscapes. Landscape Planning. Amsterdam. 8: 69-87.

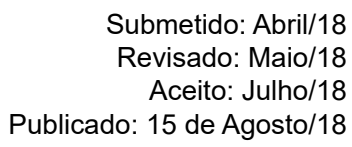

Submetido: Abril/18

Publicado: 15 de Agosto/18 